\title{
Synthesis of Arylene Ether-Type Hyperbranched Poly(triphenylamine) for Lithium Battery Cathodes
}

\author{
Inah Kang ${ }^{1,+}{ }^{+}$, Taewoong Lee ${ }^{2,+}$, Young Rok Yoon ${ }^{1}$, Jee Woo Kim ${ }^{3}$, Byung-Kwon Kim ${ }^{3}$, Jinhee Lee ${ }^{1,4, *}$, \\ Jin Hong Lee ${ }^{2, *}$ and Sang Youl Kim ${ }^{1, *}$ \\ 1 Department of Chemistry, Korea Advanced Institute of Science and Technology (KAIST), \\ Daejeon 34141, Korea; gk0784@kaist.ac.kr (I.K.); yoonyr396@kaist.ac.kr (Y.R.Y.) \\ 2 School of Chemical Engineering, Pusan National University, Busan 46421, Korea; wmfrlwk12@naver.com \\ 3 Department of Chemistry and Nanoscience, Ewha Womans University, Seoul 03760, Korea; \\ jw1603052@gmail.com (J.W.K.); kimb@ewha.ac.kr (B.-K.K.) \\ 4 Reliability Assessment Center for Chemical Materials, Korea Research Institute of Chemical \\ Technology (KRICT), Daejeon 34114, Korea \\ * Correspondence: jinhee@krict.re.kr (J.L.); jinhong.lee@pusan.ac.kr (J.H.L.); kimsy@kaist.ac.kr (S.Y.K.) \\ † Inah Kang and Taewoong Lee contributed equally to this work.
}

Citation: Kang, I.; Lee, T.; Yoon, Y.R.; Kim, J.W.; Kim, B.-K.; Lee, J.; Lee, J.H.; Kim, S.Y. Synthesis of Arylene Ether-Type Hyperbranched Poly(triphenylamine) for Lithium Battery Cathodes. Materials 2021, 14, 7885. https://doi.org/10.3390/ ma14247885

Academic Editor: Cai Shen

Received: 30 October 2021

Accepted: 16 December 2021

Published: 20 December 2021

Publisher's Note: MDPI stays neutral with regard to jurisdictional claims in published maps and institutional affiliations.

Copyright: (c) 2021 by the authors. Licensee MDPI, Basel, Switzerland. This article is an open access article distributed under the terms and conditions of the Creative Commons Attribution (CC BY) license (https:/ / creativecommons.org/licenses/by/ $4.0 /)$.

\begin{abstract}
We synthesized a new poly(triphenylamine), having a hyperbranched structure, and employed it in lithium-ion batteries as an organic cathode material. Two types of monomers were prepared with hydroxyl groups and nitro leaving groups, activated by a trifluoromethyl substituent, and then polymerized via the nucleophilic aromatic substitution reaction. The reactivity of the monomers differed depending on the number of hydroxyl groups and the $\mathrm{A}_{2} \mathrm{~B}$ type monomer with one hydroxyl group successfully produced poly(triphenylamine). Based on thermal, optical, and electrochemical analyses, a composite poly(triphenylamine) electrode was made. The electrochemical performance investigations confirmed that the lithium-ion batteries, fabricated with the poly(triphenylamine)based cathodes, had reasonable specific capacity values and stable cycling performance, suggesting the potential of this hyperbranched polymer in cathode materials for lithium-ion batteries.
\end{abstract}

Keywords: triphenylamine; $\mathrm{S}_{\mathrm{N}}$ Ar reaction; hyperbranched poly(triphenylamine); lithium-ion battery; polymer cathode

\section{Introduction}

Organic charge-transporting materials have been extensively applied in opto-electronic devices [1,2]. They transport charge carriers, i.e., holes and electrons, as well as generate charge carriers in response to external stimuli [3]. The electronic structure and processability of organic charge-transport materials can be tuned by chemical modification, and opto-electronic devices can be fabricated with organic charge-transporting polymeric materials by using low-cost approaches, such as solution processes [4-7]. Various types of conductive polymers with $\pi$-conjugation, such as polythiophene, polypyrrole, and polyaniline, have been synthesized and have shown excellent performance in opto-electronic devices [8-11].

The efficient charge transfer abilities of conductive polymers have also been utilized in organic cathode materials for lithium-ion batteries (LIBs) [12-17]. By replacing the redoxactive transition metals, conventionally used in cathodes, with conductive polymers, it has been possible to fabricate a system that has high oxidation stability in air and an intrinsically high surface area for small reactants, leading to high capacitive behaviors [18-21]. Additionally, the conductive pathways of the long-conjugated polymer chains can facilitate redox electron transfer and reduce electrode/electrolyte interface resistance, allowing for a high-rate capability. However, because the charge centers are not separated electronically, they strongly affect each other, and thus, only a limited number of active moieties 
are involved during charging/discharging, resulting in an increase in cell polarization. For these reasons, recent studies have focused more on polymers with a nonconductive backbone that bear electroactive pendant groups and organic radicals because of their localized redox sites [22,23].

Poly(triphenylamine) is one of the representative conductive polymers. It transports positive charges, via a stable radical cation, on its nitrogen atom [24]. The propeller shaped triphenylamine provides a large surface area that is highly favorable to ion transfer [25-29]. It also possesses a partially conjugated system, attributed to the limited $\pi$-conjugation of the triphenylamine unit at its neutral state [30]. Such properties create an effect, similar to those in existing polymers, which contains electroactive pendant groups, when applied to LIBs. Indeed, poly(triphenylamine) has been applied to LIBs, accompanied by various structures with linear, hyperbranched, or highly cross-linked morphology. Most of them have shown promising performance and high reproducibility [31-43]. Among them, hyperbranched polymers with a large surface area enhance LIB performance compared to linear type polymers. Furthermore, a propeller shaped structure of triphenylamine effectively reduces the $\pi-\pi$ stacking between the polymer chains. Therefore, introducing the triphenylamine unit into a highly branched structure can provide enhanced electrolyte diffusion and eventually improve the LIB performance compared to the linear type polymers. Unlike the highly crosslinked polymers, in addition, hyperbranched polymers have good solubility in organic solvents, which allows them a solution-based fabrication [44-47].

Here, we report a new type of hyperbranched poly(triphenylamine) for a LIB cathode. The poly(triphenylamine) synthesized in this study consists of triphenylamine and arylene ether units that are expected to provide high thermal and dimensional stability $[48,49]$. There are several methods for producing the hyperbranched polymers, for example, by reacting a single monomer with multifunctional reaction sites $\left(\mathrm{AB}_{n}\right.$ or latent $\mathrm{AB}_{n}$ type $)$ or multiple monomers simultaneously [44]. We firstly prepared two kinds of monomer, $\mathrm{AB}_{2}$ and $\mathrm{A}_{2} \mathrm{~B}$, which contained hydroxyl groups and nitro leaving groups, activated by a trifluoromethyl group at the ortho position, as highlighted in Figure 1. However, only the $\mathrm{A}_{2} \mathrm{~B}$ type monomer produces the desired hyperbranched polymer due to its reactivity. Subsequently, the polymer was utilized as a cathode material for LIBs. We investigated the electrochemical performances of cells fabricated with the poly(triphenylamine)-based cathode via cyclic voltammetry, rate capability, and long-term cycling stability evaluation.

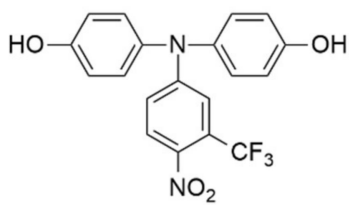

$\mathrm{AB}_{2}$ type

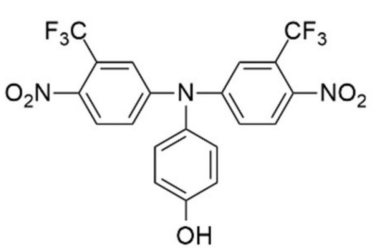

$A_{2} B$ type

Figure 1. Monomer structure.

\section{Materials and Methods}

\subsection{Materials}

Tris (dibenzylideneacetone) dipalladium $(0)\left(\mathrm{Pd}_{2}(\mathrm{dba})_{3}\right), 2,2^{\prime}$-bis (diphenylphosphino)1, $1^{\prime}$-binaphthalene (BINAP), sodium tert-butoxide $(\mathrm{NaO} t \mathrm{Bu})$, anhydrous dimethylacetamide (DMAc), anhydrous toluene, pyridine hydrochloride, ferrocene, and tetrabutylammonium hexafluorophosphate (TBAHFP) were purchased from Sigma Aldrich. $p$-Anisidine, 4-bromoanisole, and 5-bromo-2-nitrobenzotrifluoride were purchased from TCI. 1,2-Dimethoxyethane (DME), potassium phosphate $\left(\mathrm{K}_{3} \mathrm{PO}_{4}\right)$, acetone, and benzene were purchased from Junsei Chemical. Acetonitrile was purchased from Daejung. All commercially available reagent-grade chemicals were used without additional purification. 


\subsection{Material Characterization}

${ }^{1} \mathrm{H}$ and ${ }^{13} \mathrm{C}$ NMR (nuclear magnetic resonance) spectra of synthesized materials were recorded on an Agilent Technologies DD2 600 spectrometer. Chemical shifts were expressed in ppm (part per million), with reference to the peaks of residual DMSO for ${ }^{1} \mathrm{H}(2.49 \mathrm{ppm})$ and ${ }^{13} \mathrm{C}$ (39.52 ppm). Mass spectra were taken with microTOF-Q II, and elemental analysis was obtained with FLASH 200 series. FT-IR (Fourier transform infrared spectroscopy) spectra were recorded on a Varian Cary5000. Molecular weights and molecular weight distributions of polymers were obtained by size exclusion chromatography (SEC). The SEC traces were taken using a Viscotek TDA302 device (Malvern, UK) that is equipped with a refractive index detector and three PL gel $10 \mu \mathrm{m}$ MIXED-B columns, with tetrahydrofuran as an eluent, at $36{ }^{\circ} \mathrm{C}$. The weight and number of the average molecular weights of the polymers were calibrated compared to linear polystyrene standards. TGA (Thermogravimetry analysis) and DSC (differential scanning calorimetry) were conducted on a TA Instruments TGA Q500 and a DSC Q20, respectively. The TGA and DSC measurements were performed, under a nitrogen atmosphere, at a heating rate of $10^{\circ} \mathrm{C} / \mathrm{min}$. $T_{\mathrm{g}}$ values were taken from the 2nd heating scan of the DSC thermograms after cooling from $300^{\circ} \mathrm{C}$ to $0{ }^{\circ} \mathrm{C}$. UV/Vis absorption spectra were obtained on Thermo Fisher Scientific Nicolet 5700 in acetone. X-ray photoelectron spectroscopy (XPS) measurements were performed with a Kratos AXIS Supra (Manchester, UK). Scanning electron microscope was used to observe the morphology of a polymeric cathode using a Zeiss SUPRA 25 (Oberkochen, Germany). The electrochemical experiments were carried out using a $\mathrm{CH}$ instrument (CHI $630 \mathrm{E}$ potentiostat) equipped with a three-electrode system. Pt wire was used as a counter electrode, and silver/silver nitrate $\left(\mathrm{Ag} / \mathrm{AgNO}_{3}\right)$ was used as a reference electrode. A $2 \mathrm{~mm}$ diameter gold disk was employed as a working electrode. All potentials were referenced against the $\mathrm{Ag} / \mathrm{Ag}^{+}$redox couple. Values of $\mathrm{E}_{1 / 2}$ of the ferrocene/ferrocenium ion couple were $0.0915 \mathrm{~V}$ in this experimental condition.

\subsection{Synthesis of the $A B_{2}$ Type Monomer}

2.3.1. Bis(4-methoxyphenyl)amine (1)

To a two-necked round-bottomed flask (RBF) having a reflux condenser, $p$-anisidine (5.419 g, $33 \mathrm{mmol})$, 4-bromoanisole $(7.482 \mathrm{~g}, 40 \mathrm{mmol}), \mathrm{Pd}_{2}(\mathrm{dba})_{3}(0.183 \mathrm{~g}, 0.2 \mathrm{mmol})$, BINAP $(0.373 \mathrm{~g}, 0.6 \mathrm{mmol}), \mathrm{NaOtBu}(5.382 \mathrm{~g}, 56 \mathrm{mmol})$, and anhydrous toluene $(60 \mathrm{~mL})$ were added, and the reaction mixture was stirred at $120^{\circ} \mathrm{C}$ for $12 \mathrm{~h}$ under nitrogen gas flow. The reaction solution was allowed to cool to room temperature, diluted with ethyl acetate, and washed with water. After drying of the product with magnesium sulfate and removal of the solvent, the crude product was purified by column chromatography on silica gel (ethyl acetate: hexane $=1: 10$ ). The product was recrystallized from ethyl acetate and hexane mixed solvent to give $6.170 \mathrm{~g}(67 \%)$ of a white solid 1 .

${ }^{1} \mathrm{H}$ NMR (DMSO-d6, $\left.600 \mathrm{MHz}, \mathrm{ppm}\right): 7.50(\mathrm{~s}, 1 \mathrm{H}), 6.92(\mathrm{~d}, J=8,9 \mathrm{~Hz}, 4 \mathrm{H}), 6.80(\mathrm{~d}$, $J=8.9 \mathrm{~Hz}, 4 \mathrm{H}), 3.67(\mathrm{~s}, 6 \mathrm{H}) .{ }^{13} \mathrm{C}$ NMR (DMSO-d6, $\left.150 \mathrm{MHz}, \mathrm{ppm}\right): 152.83,138.05,118.04$, 114.54, 55.20. Anal. Calcd. for $\mathrm{C}_{14} \mathrm{H}_{15} \mathrm{NO}_{2}$ : C, 73.34; $\mathrm{H}, 6.59 ; \mathrm{N}, 6.11 ; \mathrm{O}, 13.96$. Found: C, 72.76; H, 6.43; N, 5.63; O, 13.13. ESI-MS: N/A (Calcd. for [M]: 229.11).

\subsubsection{Bis(4-methoxyphenyl)-(4-nitro-3-trifluoromethylphenyl)amine (2)}

While already having a reflux condenser, $1(3.837 \mathrm{~g}, 16.74 \mathrm{mmol}), 5$-bromo-2-nitrobenzotrifluoride $(4.971 \mathrm{~g}, 18.41 \mathrm{mmol}), \mathrm{Pd}_{2}(\mathrm{dba})_{3}(0.077 \mathrm{~g}, 0.084 \mathrm{mmol}), \operatorname{BINAP}(0.208 \mathrm{~g}$, $0.335 \mathrm{mmol}), \mathrm{K}_{3} \mathrm{PO}_{4}(4.973 \mathrm{~g}, 23.430 \mathrm{mmol})$, and DME $(50 \mathrm{~mL})$ were added to a two-necked $\mathrm{RBF}$. The reaction mixture was stirred at $100^{\circ} \mathrm{C}$ for $24 \mathrm{~h}$ under nitrogen atmosphere. The reaction solution was allowed to reach room temperature, diluted with ethyl acetate, and washed with water. After the drying of the product with magnesium sulfate and removing of the solvent, the crude product was purified by column chromatography on silica gel (ethyl acetate:hexane $=1: 3$ ). The final product was recrystallized from ethyl acetate/hexane mixed solvent to afford $6.747 \mathrm{~g}$ ( $96 \%$ yield) of an orange solid 2 . 
${ }^{1} \mathrm{H}$ NMR (DMSO-d6, $\left.600 \mathrm{MHz}, \mathrm{ppm}\right): 8.04(\mathrm{~d}, J=9.2 \mathrm{~Hz}, 1 \mathrm{H}), 7.16$ (dd, $J=167.1$, $8.9 \mathrm{~Hz}, 8 \mathrm{H}), 6.88(\mathrm{~d}, J=2.7 \mathrm{~Hz}, 1 \mathrm{H}), 6.80(\mathrm{dd}, J=9.2,2.7 \mathrm{~Hz}, 1 \mathrm{H}), 3.76(\mathrm{~s}, 6 \mathrm{H}) .{ }^{13} \mathrm{C} \mathrm{NMR}$ (DMSO-d6, $150 \mathrm{MHz}, \mathrm{ppm}):$ 157.99, 152.85, 136.79, 136.06, 129.07, 124.25 (q, JC-F $=32.4 \mathrm{~Hz})$, $122.17\left(\mathrm{q}, J_{\mathrm{C}-\mathrm{F}}=273.0 \mathrm{~Hz}\right), 116.77,115.60,112.67\left(\mathrm{q}, J_{\mathrm{C}-\mathrm{F}}=6.5 \mathrm{~Hz}\right), 55.34$. Anal. Calcd. for $\mathrm{C}_{21} \mathrm{H}_{17} \mathrm{~F}_{3} \mathrm{~N}_{2} \mathrm{O}_{4}: \mathrm{C}, 60.29 ; \mathrm{H}, 4.10 ; \mathrm{F}, 13.62 ; \mathrm{N}, 6.70 ; \mathrm{O}, 15.30$. Found: $\mathrm{C}, 60.04 ; \mathrm{H}, 3.79 ; \mathrm{N}$, 6.62; O, 15.59. ESI-MS: 441.10 for $[\mathrm{M}+\mathrm{Na}]^{+}$(Calcd. for [M]: 418.11).

\subsection{Synthesis of the $A_{2} B$ Type Monomer}

(4-Methoxyphenyl)-bis(4-nitro-3-trifluoromethylphenyl)amine (3)

While already having a reflux condenser, 5-bromo-2-nitrobenzotrifluoride $(8.910 \mathrm{~g}$, $33 \mathrm{mmol}), p$-anisidine $(1.847 \mathrm{~g}, 15 \mathrm{mmol}), \mathrm{Pd}_{2}(\mathrm{dba})_{3}(0.137 \mathrm{~g}, 0.15 \mathrm{mmol}), \operatorname{BINAP}(0.373 \mathrm{~g}$, $0.6 \mathrm{mmol}), \mathrm{K}_{3} \mathrm{PO}_{4}(8.915 \mathrm{~g}, 42 \mathrm{mmol})$, and DME $(70 \mathrm{~mL})$ were added to a two-necked RBF and stirred at $100{ }^{\circ} \mathrm{C}$ for $36 \mathrm{~h}$ in nitrogen atmosphere. The reaction solution was cooled to room temperature, diluted with ethyl acetate, and washed with water. After the drying of the product with magnesium sulfate and removing of the solvent, the crude product was purified by column chromatography on silica gel (ethyl acetate:hexane $=1: 5$ ). The product was recrystallized from ethyl acetate/hexane mixed solvent to give $7.064 \mathrm{~g}$ ( $94 \%$ yield) of an orange solid.

${ }^{1} \mathrm{H}$ NMR (DMSO-d6, $\left.600 \mathrm{MHz}, \mathrm{ppm}\right): 8.14(\mathrm{~d}, J=8.9 \mathrm{~Hz}, 2 \mathrm{H}), 7.49(\mathrm{~m}, 4 \mathrm{H}), 7.21(\mathrm{dd}$, $J=149.8,8.6 \mathrm{~Hz}, 4 \mathrm{H}), 3.80$ (s, 3H). ${ }^{13} \mathrm{C}$ NMR (DMSO-d6, $\left.150 \mathrm{MHz}, \mathrm{ppm}\right): 158.66,150.01$, $141.17,136.01,129.28,128.39,125.41,123.90\left(q, J_{C-F}=33.4 \mathrm{~Hz}\right), 121.85$ (q, JC-F $\left.=273.3 \mathrm{~Hz}\right)$, $120.30\left(\mathrm{q}, J_{\mathrm{C}-\mathrm{F}}=5.8 \mathrm{~Hz}\right), 116.05,55.39$. Anal. Calcd. for $\mathrm{C}_{21} \mathrm{H}_{13} \mathrm{~F}_{6} \mathrm{~N}_{3} \mathrm{O}_{5}: \mathrm{C}, 50.31 ; \mathrm{H}, 2.61$; F, 22.74; N, 8.38; O, 15.96. Found: C, 48.79; H, 2.08; N, 7.21; O, 17.22. ESI-MS: 524.07 for $[\mathrm{M}+\mathrm{Na}]^{+}$(Calcd. for [M]: 501.08).

\subsection{Deprotection of Methoxy Groups}

A $250 \mathrm{~mL}$ RBF equipped with a condenser was charged with $1 \mathrm{mmol}$ of the monomer and $33 \mathrm{mmol}$ of pyridine hydrochloride was heated to $210{ }^{\circ} \mathrm{C}$ for $1 \mathrm{~h}$. The reaction solution was cooled to room temperature and then diluted with water. After extraction of the product with ethyl acetate, it was washed with water. After drying of the product with magnesium sulfate, the excess solvent was removed.

\subsubsection{Bis(4-hydroxyphenyl)-(4-nitro-3-trifluoromethylphenyl)amine (4)}

Deprotection of monomer $2(5.076 \mathrm{~g}, 12.14 \mathrm{mmol})$ was carried out with pyridine hydrochloride. The product was purified by column chromatography in silica gel (ethyl acetate: hexane $=1: 2$ ) and recrystallized from ethyl cyclohexane/methylene chloride to afford $4.010 \mathrm{~g}$ (79\% yield) of a yellow solid.

${ }^{1} \mathrm{H}$ NMR (DMSO-d6, $\left.600 \mathrm{MHz}, \mathrm{ppm}\right): 9.72$ (s, 2H), 8.02 (d, J = 9.3 Hz, 1H), 7.01 (dd, $J=193.8,8.8 \mathrm{~Hz}, 6 \mathrm{H}), 6.82(\mathrm{~s}, 1 \mathrm{H}), 6.74(\mathrm{~d}, J=9.3 \mathrm{~Hz}, 1 \mathrm{H}) .{ }^{13} \mathrm{C}$ NMR (DMSO-d6, $150 \mathrm{MHz}$, ppm): 156.46, 153.24, 135.59, 135.36, 129.16, 128.61, 124.33 (q, JC-F $=32.2 \mathrm{~Hz}), 122.27$ (q, $\left.J_{\mathrm{C}-\mathrm{F}}=273.0 \mathrm{~Hz}\right), 116.92,116.18,112.28\left(\mathrm{q}, J_{\mathrm{C}-\mathrm{F}}=6.4 \mathrm{~Hz}\right)$. Anal. Calcd. for $\mathrm{C}_{19} \mathrm{H}_{13} \mathrm{~F}_{3} \mathrm{~N}_{2} \mathrm{O}_{4}: \mathrm{C}$, 58.47; H, 3.36; F, 14.60; N, 7.18; O, 16.40. Found: C, 55.05; H, 3.26; N, 6.73; O, 17.30. ESI-MS: 413.07 for $[\mathrm{M}+\mathrm{Na}]^{+}$(Calcd. for $\left.[\mathrm{M}]: 390.08\right)$.

\subsubsection{4-(Bis(4-nitro-3-trifluoromethylphenyl)amino)phenol (5)}

Deprotection of monomer $3(6.490 \mathrm{~g}, 12.95 \mathrm{mmol})$ was carried out with pyridine hydrochloride. The product was purified by column chromatography in silica gel (ethyl acetate: hexane $=1: 3)$ and recrystallized from ethyl acetate/hexane to afford $5.385 \mathrm{~g}(83 \%$ yield) of an orange solid.

${ }^{1} \mathrm{H}$ NMR (DMSO-d6, $\left.600 \mathrm{MHz}, \mathrm{ppm}\right): 9.92(\mathrm{~s}, 1 \mathrm{H}), 8.14(\mathrm{~d}, J=8.8 \mathrm{~Hz}, 2 \mathrm{H}), 7.49-7.45$ (m, 4H), 7.04 (dd, J = 180.2, 8.7 Hz, 4H). ${ }^{13} \mathrm{C}$ NMR (DMSO-d6, $150 \mathrm{MHz}, \mathrm{ppm}$ ): 157.19, 150.06, 140.98, $134.41,129.37,128.40,125.19,123.80\left(q, J_{C-F}=33.1 \mathrm{~Hz}\right), 121.87\left(q, J_{C-F}=273.2 \mathrm{~Hz}\right), 120.11(q$, $\left.J_{C-F}=5.6 \mathrm{~Hz}\right), 117.40$. Anal. Calcd. for $\mathrm{C}_{20} \mathrm{H}_{11} \mathrm{~F}_{6} \mathrm{~N}_{3} \mathrm{O}_{5}: \mathrm{C}, 49.29 ; \mathrm{H}, 2.28 ; \mathrm{F}, 23.39 ; \mathrm{N}, 8.62 ; \mathrm{O}$, 
16.42. Found: C, 58.72; H, 3.85; N, 5.24; O, 18.46. ESI-MS: 510.05 for $[\mathrm{M}+\mathrm{Na}]^{+}$(Calcd. for [M]: 487.31).

\subsection{Potassium Phenoxides Formation of Monomer}

Monomer 4 or $5(1 \mathrm{mmol})$ and $50 \mathrm{~mL}$ of methanol were charged into a $250 \mathrm{~mL}$ RBF. Potassium hydroxide $(0.99 \mathrm{mmol})$ was dissolved in methanol $(20 \mathrm{~mL})$, and the solution was poured slowly into the flask at $0{ }^{\circ} \mathrm{C}$. The mixture was stirred at room temperature for $1 \mathrm{~h}$. Solvent was removed by a rotary evaporator, and then acetone $(100 \mathrm{~mL})$ was added to the flask. The reaction mixture was filtered and washed with dichloromethane. The mixture was dried in a vacuum oven to afford the product, quantitatively. The monomer potassium phenoxides prepared (designated as $4-\mathrm{K}$ and $5-\mathrm{K}$ ) were characterized by ${ }^{1} \mathrm{H}$ and ${ }^{13} \mathrm{C}$ NMR spectroscopies.

4-K ${ }^{1} \mathrm{H}$ NMR (DMSO-d6, $\left.600 \mathrm{MHz}, \mathrm{ppm}\right): 8.01(\mathrm{~d}, J=9.4 \mathrm{~Hz}, 1 \mathrm{H}), 7.07(\mathrm{~d}, J=8.2 \mathrm{~Hz}$, $4 \mathrm{H}), 6.81(\mathrm{~s}, 1 \mathrm{H}), 6.74(\mathrm{~d}, J=8.3 \mathrm{~Hz}, 4 \mathrm{H}), 6.72(\mathrm{~s}, 1 \mathrm{H}) .{ }^{13} \mathrm{C}$ NMR (DMSO-d6, $150 \mathrm{MHz}$, ppm): 158.53, 153.51, 135.05, 133.91, 129.21, 128.35, $124.30\left(\mathrm{q}_{1} \mathrm{~J}_{\mathrm{C}-\mathrm{F}}=32.3 \mathrm{~Hz}\right), 122.28(\mathrm{q}$, $\left.\mathrm{J}_{\mathrm{C}-\mathrm{F}}=272.8 \mathrm{~Hz}\right), 117.20,115.78,112.01\left(\mathrm{q}, \mathrm{J}_{\mathrm{C}-\mathrm{F}}=6.6 \mathrm{~Hz}\right)$.

5-K ${ }^{1} \mathrm{H}$ NMR (DMSO-d6, $\left.600 \mathrm{MHz}, \mathrm{ppm}\right): 8.12(\mathrm{~d}, \mathrm{~J}=9.4 \mathrm{~Hz}, 2 \mathrm{H}), 7.47(\mathrm{~d}, \mathrm{~J}=6.0 \mathrm{~Hz}$, $4 \mathrm{H}), 6.87(\mathrm{dd}, \mathrm{J}=172.7,8.2 \mathrm{~Hz}, 4 \mathrm{H}) .{ }^{13} \mathrm{C}$ NMR (DMSO-d6, $150 \mathrm{MHz}, \mathrm{ppm}$ ): 162.74, 150.30, $140.58,130.39,128.92,128.38,124.71,123.63\left(\mathrm{q}, J_{\mathrm{C}-\mathrm{F}}=33.2 \mathrm{~Hz}\right), 121.89\left(\mathrm{q}, J_{\mathrm{C}-\mathrm{F}}=273.0 \mathrm{~Hz}\right)$, $119.83\left(\mathrm{q}, J_{\mathrm{C}-\mathrm{F}}=5.9 \mathrm{~Hz}\right), 118.38$.

\subsection{Polymerization}

A $25 \mathrm{~mL}$ of three-necked RBF, having a nitrogen inlet, Dean-Stark trap, mechanical stirrer, and a reflux condenser, was charged with monomer (1.5 g, $3.1 \mathrm{mmol}), \mathrm{K}_{2} \mathrm{CO}_{3}$ $(0.7445 \mathrm{~g}, 5.4 \mathrm{mmol})$, anhydrous DMAc $(5 \mathrm{~mL})$, and benzene. The mixture was heated to $110^{\circ} \mathrm{C}$, and through the Dean-Stark trap, water was removed by azeotropic distillation of toluene for $3 \mathrm{~h}$. Then, the temperature was increased to $160^{\circ} \mathrm{C}$. The reaction mixture was polymerized for $3 \mathrm{~h}$. After the reaction mixture was cooled to room temperature, it was poured into water that was acidified with a small amount of acetic acid. The precipitated polymer was collected by filtration and further purified by the reprecipitation, of the DMAc solution of polymer, into methanol. The filtered polymer product was dried in a vacuum oven.

\subsection{Electrochemical Characterization}

The coin type CR2032 cells were fabricated in an argon-filled glove box to measure electrochemical performance. The electrode slurry was prepared at a weight ratio of $50 \mathrm{wt} \%$ of the as-prepared polymer, $10 \mathrm{wt} \%$ of polyvinylidene difluoride (PVDF), and $40 \mathrm{wt} \%$ of super P in 1-methyl-2-pyrrolidinone (Sigma Aldrich, $>99.0 \%$, St. Louis, MO, USA) solution homogenously mixed by Thinky mixer and dried for $24 \mathrm{~h}$ at $60^{\circ} \mathrm{C}$ in a vacuum oven. Lithium metal, as a counter electrode and PP separator (Celgard 2400), was used in fabrication of CR2032 (Seoul, Korea). Additionally, $1 \mathrm{M} \mathrm{LiPF}_{6}$ in 1:1 EC (ethylene carbonate)/DMC dimethyl carbonate was used as an electrolyte. Charge/discharge galvanostatic experiments were performed using an automatic battery cycler (WonATech, WBCS3000, Seoul, Korea) in the voltage range of $2.5-4.2 \mathrm{~V}$ (vs. $\mathrm{Li} / \mathrm{Li}+$ ). Rate capabilities were examined at different current densities from $20 \mathrm{~mA} / \mathrm{g}$ to $500 \mathrm{~mA} / \mathrm{g}$.

\section{Results}

\subsection{Synthesis and Characterization}

In this study, we designed two types of triphenylamine monomer, $\mathrm{A}_{2} \mathrm{~B}$ and $\mathrm{AB}_{2}$, to synthesize poly(triphenylamine)s with a hyperbranched structure. Each monomer includes a hydroxyl group (-OH) and a nitro group $\left(-\mathrm{NO}_{2}\right)$ as a leaving group for the nucleophilic aromatic substitution $\left(S_{N} A r\right)$ reaction: the $A B_{2}$ type contains two hydroxyl groups and one nitro group, with an electron-withdrawing trifluoromethyl group at the ortho position. The $\mathrm{A}_{2} \mathrm{~B}$ type, in contrast, has one hydroxyl group and two nitro groups, as described in 
Figure 1. During the reaction, the phenoxide groups attack the ipso carbon of the aromatic rings. Then the nitro-leaving groups that are activated with the trifluoromethyl groups are substituted to form the ether bonds, which results in hyperbranched poly(triphenylamine)s.

Scheme 1 summarizes our synthetic route to the monomers. $p$-Anisidine and 4-bromoanisole underwent a palladium-catalyzed amination reaction to form a diphenylamine compound 1 . The intermediate 1 was coupled with 5-bromo-2-nitrobenzotrifluoride, which produced a triphenylamine compound 2 with a methoxy-protected hydroxyl group. When the methoxy groups in 2 were deprotected with pyridine hydrochloride, an $\mathrm{AB}_{2}$ type monomer 4 was obtained. Meanwhile, coupling the 5-bromo-2-nitrobenzotrifluoride with $p$-anisidine afforded a methoxy-protected triphenylamine 3 , and the same deprotection process gave an $\mathrm{A}_{2} \mathrm{~B}$ type monomer 5 . The chemical structure of the monomers was confirmed by ${ }^{1} \mathrm{H}$ and ${ }^{13} \mathrm{C}$ NMR, as shown in Figures S1-S5.
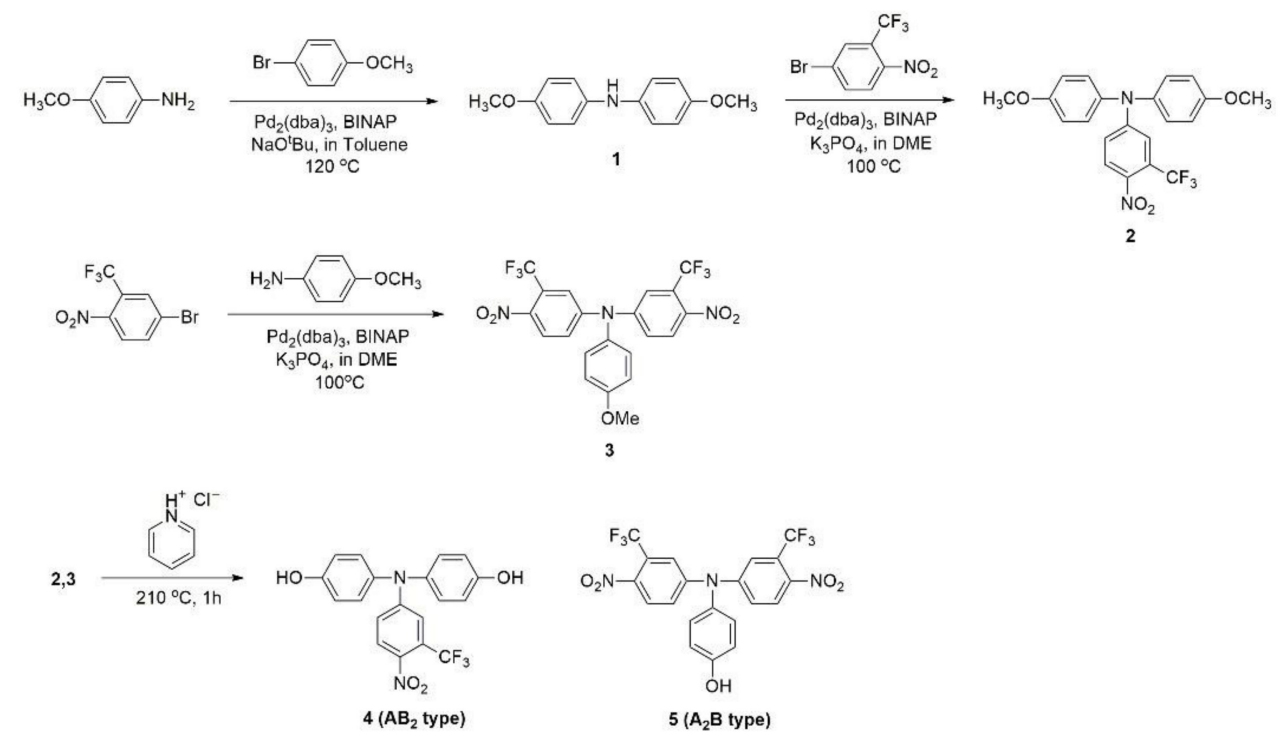

Scheme 1. Synthetic route of monomer 4 and 5.

Next, the polymerization of the two types of monomers was conducted, respectively, via the $S_{N} A r$ reaction. We reacted monomers 4 and 5 in DMAc at $160^{\circ} \mathrm{C}$ assisted by $\mathrm{K}_{2} \mathrm{CO}_{3}$ as a base catalyst, as shown in Scheme 2. To prevent a nucleophilic attack by water, it was carried out under anhydrous conditions, preceded by the azeotrope. After $3 \mathrm{~h}$, the reaction of 5 afforded the desired triphenylamine polymer (PTPA) with a 71\% yield. On the other hand, interestingly, no polymeric product for 4 was obtained.<smiles>O=[N+]([O-])c1ccc(N(c2ccc(O)cc2)c2ccc(O)cc2)cc1</smiles>

$4\left(\mathrm{AB}_{2}\right.$ type $)$<smiles>O=[N+]([O-])c1ccc(N(c2ccc(O)cc2)c2ccc([N+](=O)[O-])c(C(F)(F)F)c2)cc1</smiles>

5 ( $A_{2} B$ type)

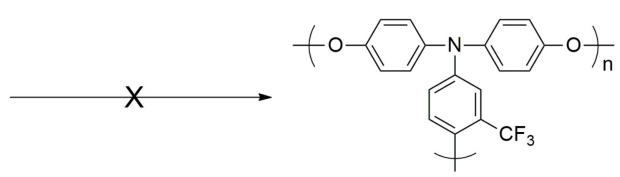

$\mathrm{K}_{2} \mathrm{CO}_{3}$

DMAc/benzene $160^{\circ} \mathrm{C}, 3 \mathrm{~h}$

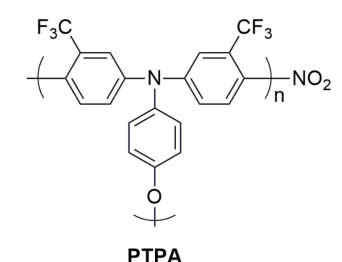

PTPA

Scheme 2. Polymerization of monomer 4 and 5.

We posited that this occurred because of the reactivity of the monomers. According to former studies [50-52], the reactivity toward nucleophiles can be proved by NMR 
spectroscopy, by comparing the spectra of the phenoxide form that was exploited during the reaction. To do so, we prepared the potassium phenoxides of monomer 4 and 5, respectively (designated as 4-K and $5-\mathrm{K}$ ), and examined the ${ }^{13} \mathrm{C}$ NMR peaks of the nitroleaving group in 4-K and 5-K (Figures S6 and S7). Figure 2 clearly shows that the peak, corresponding to an ipso carbon of the nitro group in 5-K, was highly deshielded, while the one in 4-K shows an upfield shift. This large downfield shift in 5-K indicates a deficiency of electrons in the ipso carbons because of the electrons pulled by the nitro group. This helped to activate the nitro group as the leaving group and, consequently, encouraged the successive reaction. However, the nitro group in 4-K lacked the electron-withdrawing ability that was required for the reaction, and thus, polymerization did not occur. This result supports that the number of the hydroxyl group is related to the reactivity, and the $\mathrm{A}_{2} \mathrm{~B}$ type monomer 5 , which includes less hydroxyl groups, favored the $\mathrm{S}_{\mathrm{N}} \mathrm{Ar}$ reaction.

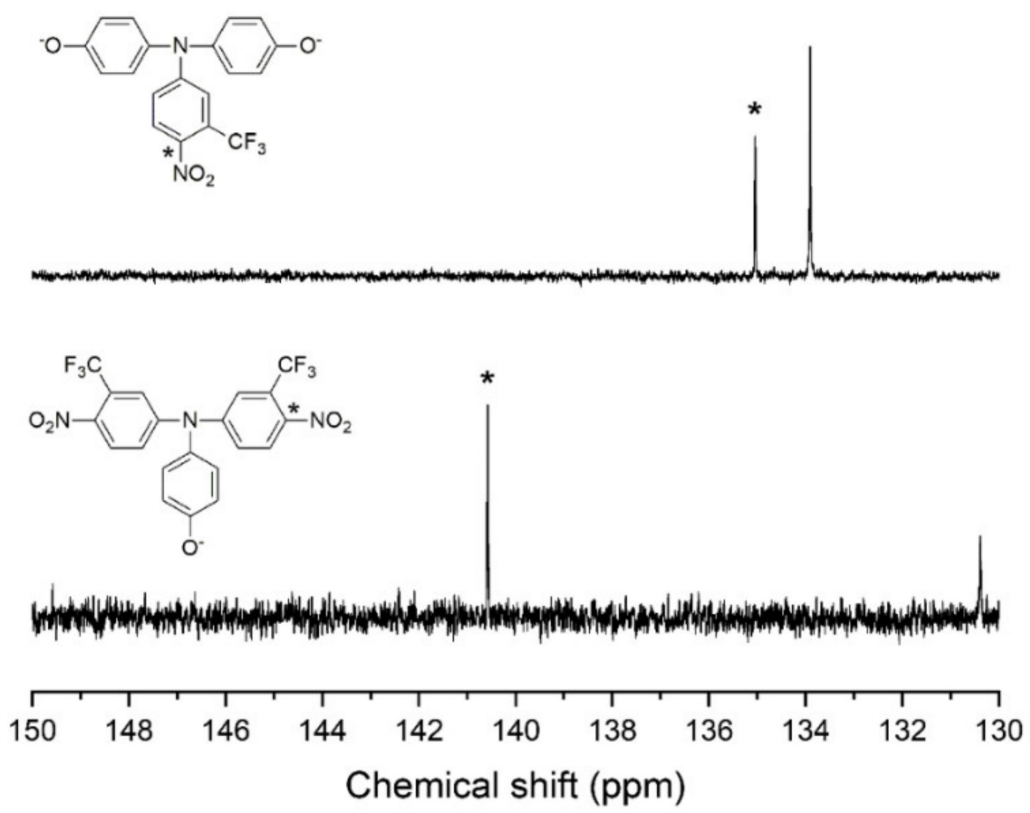

Figure 2. Chemical shift of 4-K (above) and 5-K (below) (DMSO-d6, $150 \mathrm{MHz}$ ).

To investigate further, a variety of spectroscopic techniques were used. In the ${ }^{1} \mathrm{H}$ NMR spectra of PTPA (Figure 3), a series of peaks at 6.5-8.2 ppm, corresponding to the protons of the hyperbranched aromatic rings, revealed that PTPA had been synthesized successfully. Although the undesired displacement of nitro groups can occur during the polymerization [53-56] any related peaks were not observed in the spectrum, indicating there was no side reaction. The infrared spectra of 5 and PTPA, shown in Figure S8, also supported the conclusion of polymerization. Most of the hydroxyl groups in 5 were consumed, since the associated peak at $3434 \mathrm{~cm}^{-1}$ disappeared from the PTPA spectrum. Likewise, the peak at $1575 \mathrm{~cm}^{-1}$ corresponding to N-O stretching largely diminished but still remained after the polymerization. This indicates the elimination of nitro groups from 5 as well, yet a notable amount of nitro groups remained at the end of the hyperbranched polymer. In addition, the molecular weight of the PTPA was estimated by SEC using linear polystyrene standards, as shown in Figure S9. XPS spectrum of PTPA (Figure S10) also shows the corresponding peaks, for elements $(\mathrm{C}, \mathrm{N}, \mathrm{O}, \mathrm{F})$ present in the PTPA, synthesized in this study. These results accurately confirmed that the polymerization was successful. 


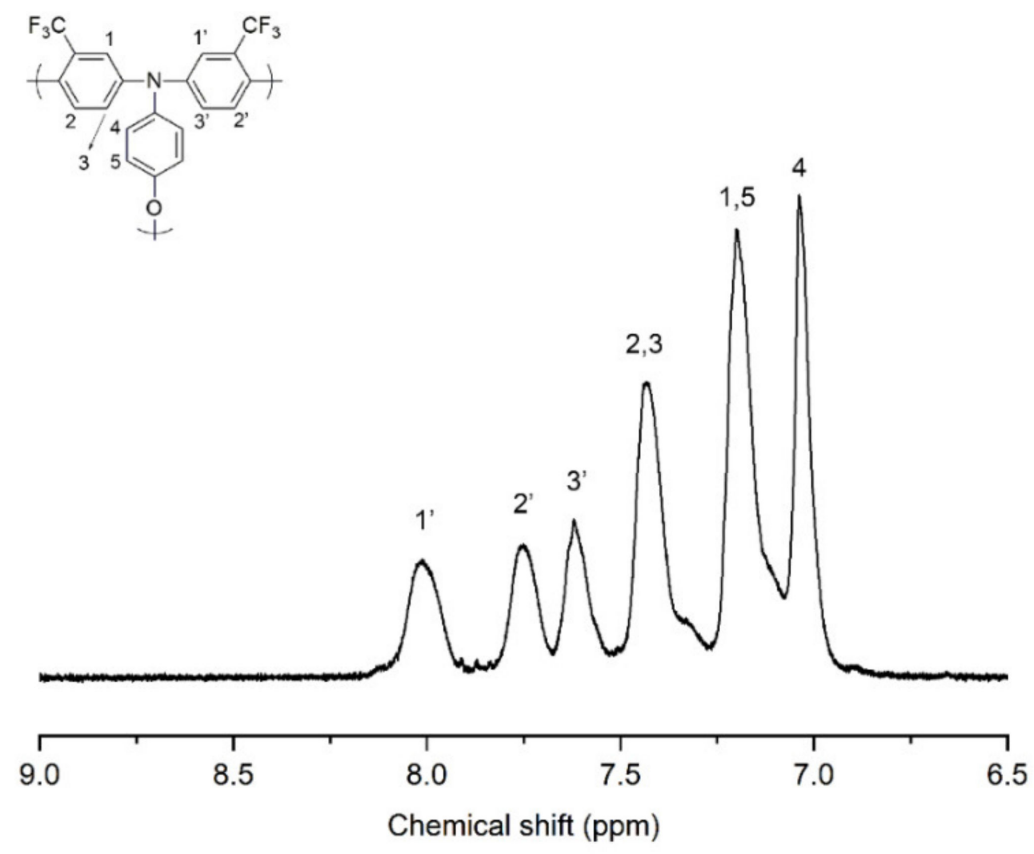

Figure 3. ${ }^{1} \mathrm{H}$ NMR spectra of PTPA (DMSO- $\left.d 6,600 \mathrm{MHz}\right)$.

TGA and DSC curves indicated the PTPA had excellent thermal properties. The 5\% weight loss temperature $\left(T_{\mathrm{d} 5}\right)$ was $417^{\circ} \mathrm{C}$, and the glass transition temperature $\left(T_{\mathrm{g}}\right)$ was observed at $202{ }^{\circ} \mathrm{C}$, with no melting transition up to $300{ }^{\circ} \mathrm{C}$. This suggests that PTPA within a cathode will not be transformed or damaged when the temperature is elevated, as summarized in Figure 4.

(a)

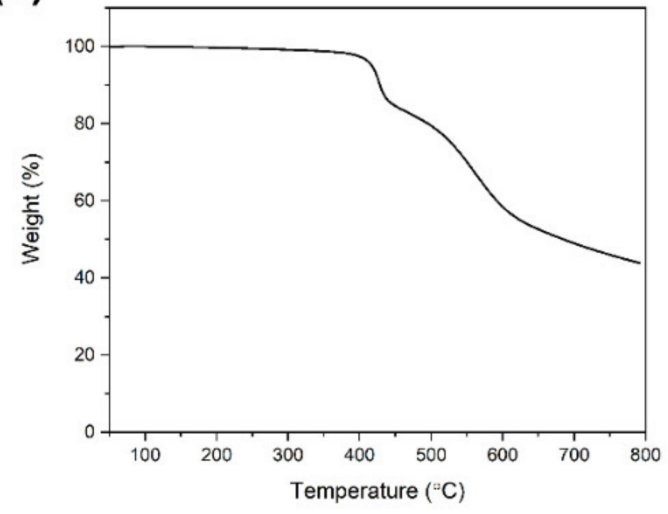

(b)

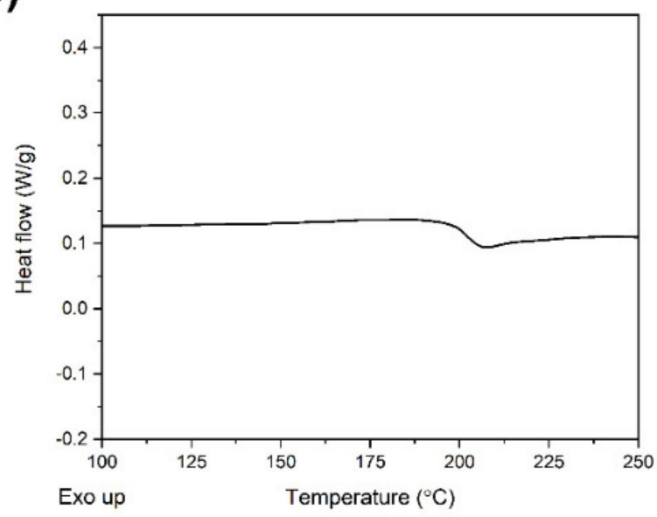

Figure 4. (a) TGA and (b) DSC thermograms of the PTPA.

Next, we investigated optical properties from the UV/Vis absorption spectra of 5 and PTPA. As depicted in Figure 5a, the maximum absorption of 5 and PTPA appeared at 403 and $390 \mathrm{~nm}$, respectively, which corresponds to the $\pi-\pi$ * electron transition from the triphenylamine units. It was observed that the absorption became blue-shifted after the polymerization, which is attributed to the decrease in the number of electron-withdrawing nitro groups. The energy gap of the PTPA, which was calculated from the onset of absorption from the UV spectrum, was $2.73 \mathrm{eV}$. 

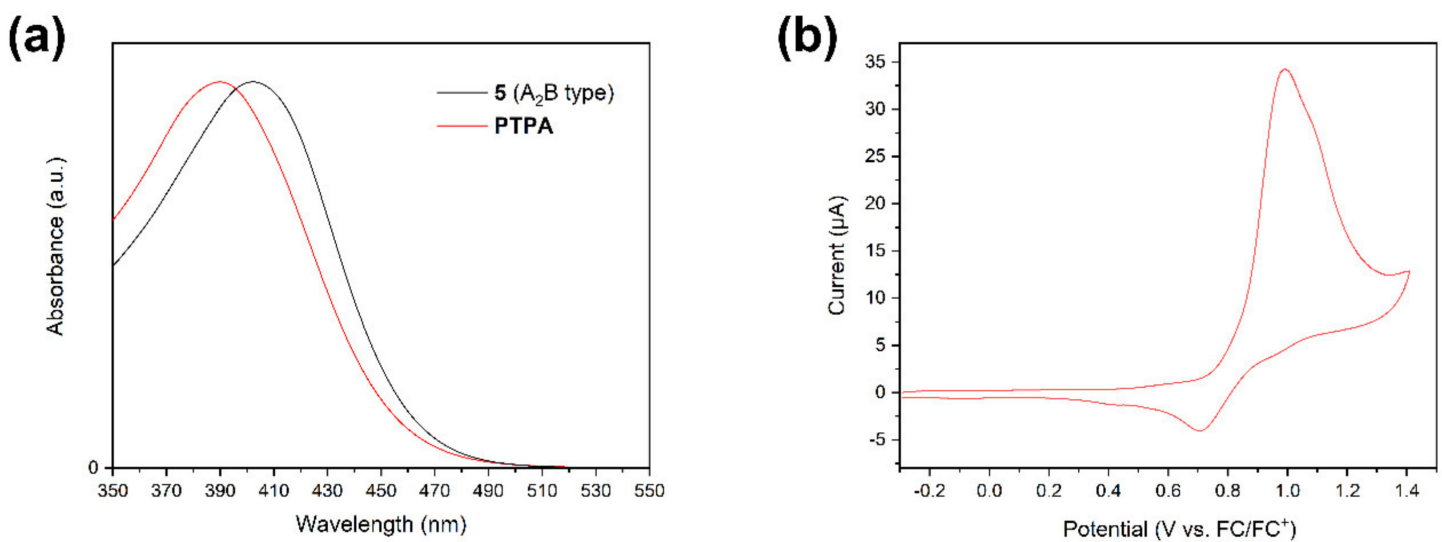

Figure 5. (a) Normalized UV/Vis spectra of 5 (black) and PTPA (red) in acetone. (b) Cyclic voltammogram of $0.1 \mathrm{mM}$ PTPA in acetonitrile, containing $100 \mathrm{mM}$ TBAHFP at a scan rate of $50 \mathrm{mV} / \mathrm{s}$.

To investigate its electronic structure, the electrochemical behavior of PTPA was recorded using cyclic voltammetry $(\mathrm{CV})$. Figure $5 \mathrm{~b}$ shows a clearly reversible $\mathrm{CV}$ curve of $0.1 \mathrm{mM}$ for PTPA, immersed in $100 \mathrm{mM}$ of TBAHFP acetonitrile solution, scanned up to $1.4 \mathrm{~V}$ of the potential. The onset of oxidation potential was $0.85 \mathrm{~V}$, which is as high as observed in our previous study, due to the trifluoromethyl groups [50]. From this voltammetry profile, the highest occupied molecular orbital (HOMO) and lowest unoccupied molecular orbitals (LUMO) of PTPA were determined to examine the electrochemical oxidation stability [57]. The HOMO energy level was calculated to be $-5.65 \mathrm{eV}$ basis on the ferrocene standard level of $4.8 \mathrm{eV}$ and the half-wave potential $\left(\mathrm{E}_{1 / 2}\right)$ of ferrocene/ferrocenium ions. Such a low HOMO energy level of PTPA has the advantage of providing electrochemical oxidation stability against ambient oxygen and humidity [50]. Considering the HOMO level and the optical energy gap, derived from the UV/Vis results above, we also deduced a LUMO energy level of $-2.92 \mathrm{eV}$.

\subsection{Electrochemical Investigation}

To evaluate the electrochemical performance of the PTPA, as a cathode in lithium ion batteries, we fabricated a CR 2032 coin-type cell with a lithium metal counter electrode. The coating on Al current collector of an organic cathode consisting of PTPA, PVDF, and Super-P (weight ratio was 5:1:4) was prepared. As shown in Figure S11, we observed the sphere-like structure of the PTPA, with an average size of $20 \mathrm{~nm}$. Moreover, elemental mapping revealed the uniform distribution of $\mathrm{C}, \mathrm{O}, \mathrm{N}$, and $\mathrm{F}$ elements over the entire electrode. The redox behavior of the cells was initially investigated by $\mathrm{CV}$ analysis, within the voltage range of $2.5-4.2 \mathrm{~V}$, at a scan rate of $0.1 \mathrm{mV} \mathrm{s}^{-1}$. As displayed in Figure $6 \mathrm{a}$, the cells exhibited two pairs of cathodic peaks (3.8-4.0 V and 4.0-4.2 V) and anodic peaks (3.8-3.9 $\mathrm{V}$ and 4.0-4.1 V). We considered that nitrogen atoms from the triphenylamine could act as the redox sites for lithium storage. As displayed in Figure 6a, the cells exhibited two pairs of cathodic peaks (3.8-4.0 $\mathrm{V}$ and $4.0-4.2 \mathrm{~V})$ and anodic peaks $(3.8-3.9 \mathrm{~V}$ and $4.0-4.1 \mathrm{~V}$ ). The well-defined redox peaks between 4.0-4.2 V were attributed to the electrochemical reactions of the lithium insertion/extraction process of the triphenylamine moieties during the charge/discharge process, while the relatively weak redox peaks, occurring at 3.8-4.0 V, correspond to the organic ligands from the triphenylamine [36,58]. After the first activation cycle, the following CV curves were observed to be highly overlaid, suggesting that the cells were able to maintain electrochemical reversibility with low polarization.

Subsequently, the rate capability of the cells was measured at different current densities, of 20,50, 100, 300, 500, and a recovery step at a current density of $20 \mathrm{~mA} \mathrm{~g}^{-1}$. As presented in Figure $6 \mathrm{~b}$, the specific capacity of the cells progressively decreased as the current density increased. The specific capacities were calculated to be 99.6, 87.8, 81.4, 73.2, and $58.3 \mathrm{~mA} \mathrm{~h} \mathrm{~g}^{-1}$ at current densities of 20,50, 100, 300, and $500 \mathrm{~mA} \mathrm{~g}^{-1}$, respectively. 
After returning to the mild condition of $20 \mathrm{~mA} \mathrm{~g}^{-1}$, the specific capacities were recovered, very close to the initial specific capacity values, again confirming high reversibility and stability during charging and discharging processes.

(a)

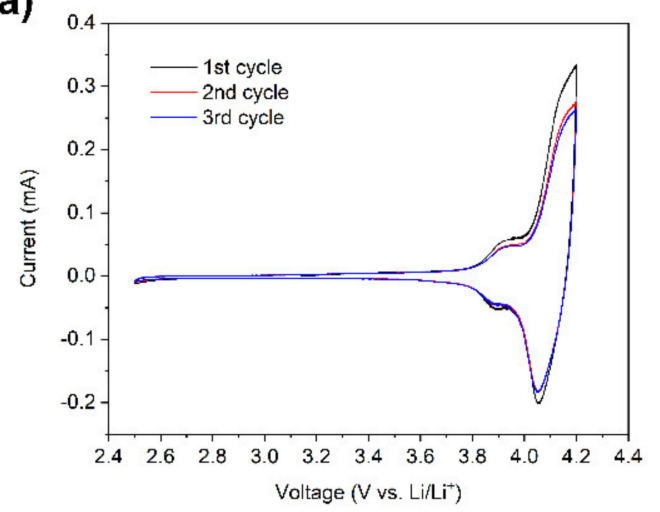

(c)

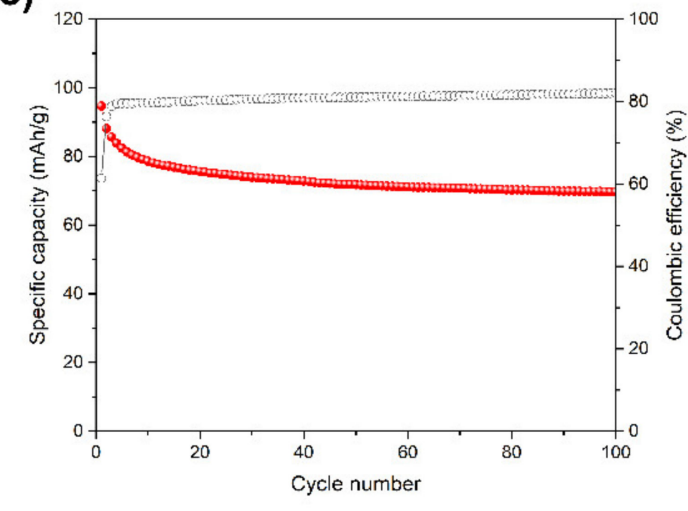

(b)

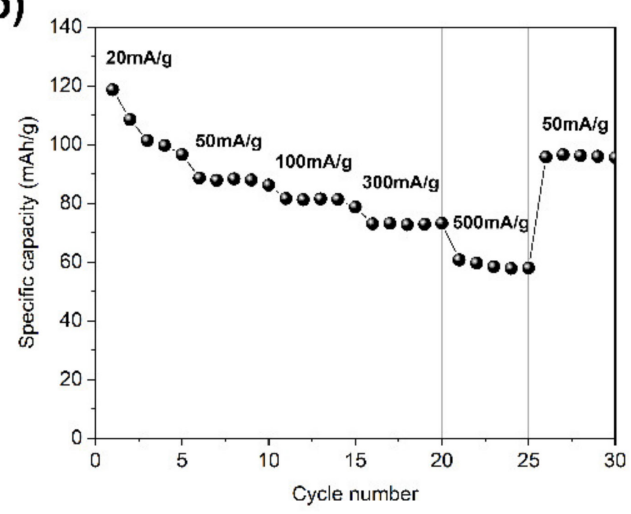

(d)

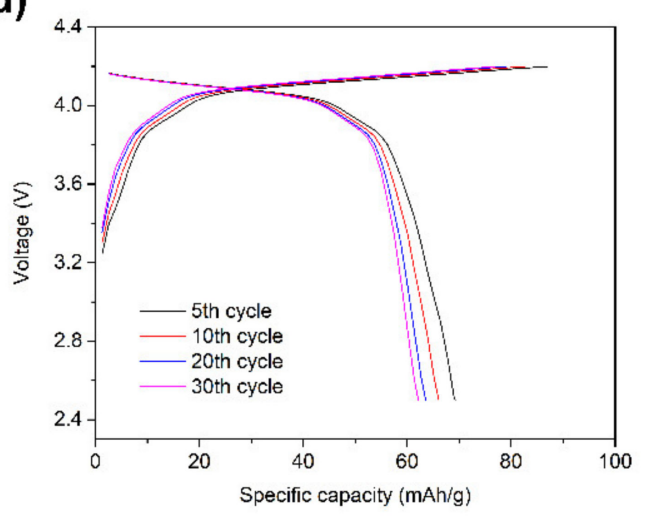

Figure 6. (a) Cyclic voltammogram of PTPA cathode at scan rate of $0.1 \mathrm{mV} / \mathrm{s}$. (b) Rate capability of PTPA cathode at various current densities of 20,50,100,300,500 mA/g, and recovery step at current rate of $50 \mathrm{~mA} / \mathrm{g}$. (c) Long cycle test of PTPA cathode, at a current rate of $50 \mathrm{~mA} / \mathrm{g}$, between 2.5-4.2 V; specific capacity (red) and coulombic efficiency (black).

(d) Corresponding charge-discharge voltage plots of PTPA cathode at 5th, 10th, 20th, and 30th cycle.

The long-term cycling performances of the cell were also examined by evaluating 100 cycles at a current density of $50 \mathrm{~mA} \mathrm{~g}^{-1}$, as shown in Figure 6c. As expected, the cells retained stable cycling behavior without a significant decay of specific capacity. The specific capacity achieved after 100 cycles was $69.7 \mathrm{~mA} \mathrm{~h} \mathrm{~g}^{-1}$, which was on a par with the initial value, except for the activation cycles at the beginning of measurement.

A further manifestation of the stable cycling performances was obtained from the galvanostatic charge-discharge (GCD) profiles at the 5th, 10th, 20th, and 30th cycle. As shown in Figure 6d, no obvious change was observed in the GCD profiles during cycling; only small electrode polarization was detected with increasing cycle number, demonstrating the high electrochemical stability and reversibility of the cells. Based on these results, we believe that the new design of hyperbranched polymers could widen the selection of cathode materials for LIBs, which may hold the key for further improvements in the electrochemical performance of the energy storage technology.

\section{Conclusions}

A new arylene-ether type hyperbranched poly(triphenylamine) was prepared by $\mathrm{S}_{\mathrm{N}}$ Ar reaction. The success of the polymerization process depended on the reactivity of the monomers, and monomer 5, which had one hydroxyl group, was successfully polymerized to PTPA. The properties of the PTPA were characterized by NMR and IR spectra, SEC, TGA and DSC thermograms, UV spectra, and cyclovoltammetry curves. Lithium batteries that 
were fabricated with the PTPA as a cathode material demonstrated excellent electrochemical reversibility and stability at various current densities. Moreover, the cells continued to maintain stable cycling behavior over repeated cycling, suggesting opportunities of the PTPA, for applications as cathode materials, in lithium batteries. However, the molecular weight of the active material increased due to the $\mathrm{CF}_{3}$ groups introduced for polymerization, but it showed a lower specific capacity compared to previous studies. To improve the battery performance, we are conducting research on end-modification of the hyperbranched polymer with electroactive moieties and the design of new monomers that can reduce the molecular weight of repeating units.

Supplementary Materials: The following are available online at https: / www.mdpi.com/article / 10.3390/ma14247885/s1, Figure S1: (a) 1H NMR spectra of 1 (DMSO-d6, 600 MHz). (b) 13C NMR spectra of 1 (DMSO-d6, $150 \mathrm{MHz}$ ), Figure S2: (a) 1H NMR spectra of 2 (DMSO-d6, $600 \mathrm{MHz}$ ). (b) 13C NMR spectra of 2 (DMSO-d6, $150 \mathrm{MHz}$ ), Figure S3: (a) 1H NMR spectra of 3 (DMSO-d6, $600 \mathrm{MHz}$ ). (b) 13C NMR spectra of 3 (DMSO-d6, $150 \mathrm{MHz}$ ), Figure S4: (a) 1H NMR spectra of 4 (DMSO-d6, $600 \mathrm{MHz}$ ). (b) 13C NMR spectra of 4 (DMSO-d6, $150 \mathrm{MHz}$ ), Figure S5: (a) 1H NMR spectra of 5 (DMSO-d6, $600 \mathrm{MHz}$ ). (b) 13C NMR spectra of 5 (DMSO-d6, $150 \mathrm{MHz}$ ), Figure S6: (a) 1H NMR spectra of 4-K (DMSO-d6, $600 \mathrm{MHz}$ ). (b) 13C NMR spectra of 4-K (DMSO-d6, $150 \mathrm{MHz}$ ), Figure S7: (a) 1H NMR spectra of 5-K (DMSO-d6, $600 \mathrm{MHz}$ ). (b) 13C NMR spectra of 5-K (DMSO-d6, $150 \mathrm{MHz}$ ), Figure S8: IR spectra of (a) 5 and (b) PTPA, Figure S9: SEC traces of PTPA (THF, $36{ }^{\circ} \mathrm{C}, 0.6 \mathrm{~mL} / \mathrm{min}$ ). Estimated molecular weight was $\mathrm{Mn}=22,200$ and $\mathrm{Mw}=303,400$. Figure S10: XPS spectrum of PTPA. Figure S11: SEM images and element mapping images of PTPA cathode.

Author Contributions: Conceptualization, J.L. and J.H.L.; methodology, J.L. and J.H.L.; synthesis, I.K. and J.L.; validation, Y.R.Y. and B.-K.K.; formal analysis, I.K., T.L. and J.W.K.; investigation, I.K. and T.L.; data curation, I.K., T.L., Y.R.Y., J.W.K. and B.-K.K.; writing-original draft preparation, I.K., T.L. and J.L.; writing-review and editing, B.-K.K., J.L., J.H.L. and S.Y.K.; visualization, I.K. and T.L.; supervision, J.L., J.H.L. and S.Y.K.; All authors have read and agreed to the published version of the manuscript.

Funding: This research was supported by Technology Innovation Program (20007228) funded by the Ministry of Trade, Industry \& Energy (MOTIE) of Korea and Institutional Research Program (SI2152-20) of the Korea Research Institute of Chemical Technology (KRICT). This research was also supported by the National Research Foundation of Korea (NRF) funded by the MSIT (Grant Numbers. NRF-2021R1A4A1022198 and NRF-2021R1A4A1052070).

Institutional Review Board Statement: Not applicable.

Informed Consent Statement: Not applicable.

Data Availability Statement: The data used in this study are available from the corresponding authors upon request.

Conflicts of Interest: The authors declare no conflict of interest.

\section{References}

1. Facchetti, A. $\pi$-Conjugated Polymers for Organic Electronics and Photovoltaic Cell Applications. Chem. Mater. 2011, 23, 733-758. [CrossRef]

2. Ibanez, J.G.; Rincón, M.E.; Gutierrez-Granados, S.; Chahma, M.; Jaramillo-Quintero, O.A.; Frontana-Uribe, B.A. Conducting Polymers in the Fields of Energy, Environmental Remediation, and Chemical-Chiral Sensors. Chem. Rev. 2018, 118, 4731-4816. [CrossRef]

3. Shirota, Y.; Kageyama, H. Charge Carrier Transporting Molecular Materials and Their Applications in Devices. Chem. Rev. 2007, 107, 953-1010. [CrossRef]

4. Gibson, H.W. Control of electrical properties of polymers by chemical modification. Polymer 1984, 25, 3-27. [CrossRef]

5. Guo, X.; Baumgarten, M.; Müllen, K. Designing $\pi$-conjugated polymers for organic electronics. Prog. Polym. Sci. 2013, 38, 1832-1908. [CrossRef]

6. Kaloni, T.P.; Schreckenbach, G.; Freund, M.S. Band gap modulation in polythiophene and polypyrrole-based systems. Sci. Rep. 2016, 6, 36554. [CrossRef]

7. Jia, X.; Ge, Y.; Shao, L.; Wang, C.; Wallace, G.G. Tunable Conducting Polymers: Toward Sustainable and Versatile Batteries. ACS Sustain. Chem. Eng. 2019, 7, 14321-14340. [CrossRef] 
8. Rittmeyer, S.P.; Groß, A. Structural and electronic properties of oligo- and polythiophenes modified by substituents. Beilstein J. Nanotechnol. 2012, 3, 909-919. [CrossRef]

9. Kumar, D.; Sharma, R.C. Advances in conductive polymers. Eur. Polym. J. 1998, 34, 1053-1060. [CrossRef]

10. Meng, Q.; Cai, K.; Chen, Y.; Chen, L. Research progress on conducting polymer based supercapacitor electrode materials. Nano Energy 2017, 36, 268-285. [CrossRef]

11. Li, Z.; Gong, L. Research Progress on Applications of Polyaniline (PANI) for Electrochemical Energy Storage and Conversion. Materials 2020, 13, 548. [CrossRef]

12. Bhosale, M.E.; Chae, S.; Kim, J.M.; Choi, J.-Y. Organic small molecules and polymers as an electrode material for rechargeable lithium ion batteries. J. Mater. Chem. A 2018, 6, 19885-19911. [CrossRef]

13. Muench, S.; Wild, A.; Friebe, C.; Häupler, B.; Janoschka, T.; Schubert, U.S. Polymer-Based Organic Batteries. Chem. Rev. 2016, 116, 9438-9484. [CrossRef]

14. Hong, X.; Liu, Y.; Li, Y.; Wang, X.; Fu, J.; Wang, X. Application Progress of Polyaniline, Polypyrrole and Polythiophene in Lithium-Sulfur Batteries. Polymers 2020, 12, 331. [CrossRef]

15. Quijada, C. Special Issue: Conductive Polymers: Materials and Applications. Materials 2020, 13, 2344. [CrossRef] [PubMed]

16. Kuo, C.-W.; Chang, J.-C.; Huang, Y.-T.; Chang, J.-K.; Lee, L.-T.; Wu, T.-Y. Applications of Copolymers Consisting of 2,6-di(9Hcarbazol-9-yl)pyridine and 3,6-di(2-thienyl)carbazole Units as Electrodes in Electrochromic Devices. Materials 2019, $12,1251$. [CrossRef] [PubMed]

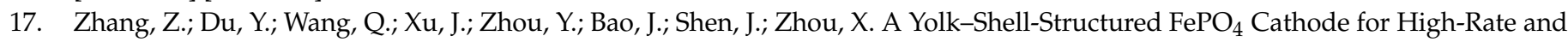
Long-Cycling Sodium-Ion Batteries. Angew. Chem. Int. Ed. 2020, 59, 17504-17510. [CrossRef]

18. Yue, L.; Liang, J.; Wu, Z.; Zhong, B.; Luo, Y.; Liu, Q.; Li, T.; Kong, Q.; Liu, Y.; Asiri, A.M.; et al. Progress and perspective of metal phosphide/carbon heterostructure anodes for rechargeable ion batteries. J. Mater. Chem. A 2021, 9, 11879-11907. [CrossRef]

19. Wijeratne, K.; Ail, U.; Brooke, R.; Vagin, M.; Liu, X.; Fahlman, M.; Crispin, X. Bulk electronic transport impacts on electron transfer at conducting polymer electrode-electrolyte interfaces. Proc. Natl. Acad. Sci. USA 2018, 115, 11899-11904. [CrossRef]

20. Xie, J.; Zhang, Q. Recent progress in rechargeable lithium batteries with organic materials as promising electrodes. J. Mater. Chem. A 2016, 4, 7091-7106. [CrossRef]

21. Zhao, W.; Gao, L.; Yue, L.; Wang, X.; Liu, Q.; Luo, Y.; Li, T.; Shi, X.; Asiri, A.M.; Sun, X. Constructing a hollow microflower-like ZnS/CuS@C heterojunction as an effective ion-transport booster for an ultrastable and high-rate sodium storage anode. J. Mater. Chem. A 2021, 9, 6402-6412. [CrossRef]

22. Janoschka, T.; Hager, M.D.; Schubert, U.S. Powering up the Future: Radical Polymers for Battery Applications. Adv. Mater. 2012, 24, 6397-6409. [CrossRef]

23. Song, Z.; Zhou, H. Towards sustainable and versatile energy storage devices: An overview of organic electrode materials. Energy Environ. Sci. 2013, 6, 2280-2301. [CrossRef]

24. Thelakkat, M. Star-Shaped, Dendrimeric and Polymeric Triarylamines as Photoconductors and Hole Transport Materials for Electro-Optical Applications. Macromol. Mater. Eng. 2002, 287, 442-461. [CrossRef]

25. Iwan, A.; Sek, D. Polymers with triphenylamine units: Photonic and electroactive materials. Prog. Polym. Sci. 2011, 36, 1277-1325. [CrossRef]

26. Wang, Z.; Zhang, B.; Yu, H.; Li, G.; Bao, Y. Synthetic control of network topology and pore structure in microporous polyimides based on triangular triphenylbenzene and triphenylamine units. Soft Matter 2011, 7, 5723-5730. [CrossRef]

27. Li, G.; Wang, Z. Microporous Polyimides with Uniform Pores for Adsorption and Separation of CO2 Gas and Organic Vapors. Macromolecules 2013, 46, 3058-3066. [CrossRef]

28. Hu, Y.-C.; Chen, C.-J.; Yen, H.-J.; Lin, K.-Y.; Yeh, J.-M.; Chen, W.-C.; Liou, G.-S. Novel triphenylamine-containing ambipolar polyimides with pendant anthraquinone moiety for polymeric memory device, electrochromic and gas separation applications. $J$. Mater. Chem. 2012, 22, 20394-20402. [CrossRef]

29. Bera, D.; Padmanabhan, V.; Banerjee, S. Highly Gas Permeable Polyamides Based on Substituted Triphenylamine. Macromolecules 2015, 48, 4541-4554. [CrossRef]

30. Liang, Y.; Tao, Z.; Chen, J. Organic Electrode Materials for Rechargeable Lithium Batteries. Adv. Energy Mater. 2012, 2, 742-769. [CrossRef]

31. Feng, J.K.; Cao, Y.L.; Ai, X.P.; Yang, H.X. Polytriphenylamine: A high power and high capacity cathode material for rechargeable lithium batteries. J. Power Sources 2008, 177, 199-204. [CrossRef]

32. Yamamoto, K.; Suemasa, D.; Masuda, K.; Aita, K.; Endo, T. Hyperbranched Triphenylamine Polymer for UltraFast Battery Cathode. ACS Appl. Mater. Interfaces 2018, 10, 6346-6353. [CrossRef] [PubMed]

33. Zhang, C.; Yang, X.; Ren, W.; Wang, Y.; Su, F.; Jiang, J.X. Microporous organic polymer-based lithium ion batteries with improved rate performance and energy density. J. Power Sources 2016, 317, 49-56. [CrossRef]

34. Xu, T.; Xiong, J.; Du, X.; Zhang, Y.; Song, S.; Xiong, C.; Dong, L. Polytriphenylamine Derivative and Carbon Nanotubes as Cathode Materials for High-Performance Polymer-Based Batteries. J. Phys. Chem. C 2018, 122, 20057-20063. [CrossRef]

35. Friebe, C.; Lex-Balducci, A.; Schubert, U.S. Sustainable Energy Storage: Recent Trends and Developments toward Fully Organic Batteries. ChemSusChem 2019, 12, 4093-4115. [CrossRef]

36. Su, C.; Yang, F.; Ji, L.; Xu, L.; Zhang, C. Polytriphenylamine derivative with high free radical density as the novel organic cathode for lithium ion batteries. J. Mater. Chem. A 2014, 2, 20083-20088. [CrossRef] 
37. Su, C.; He, H.; Xu, L.; Zhao, K.; Zheng, C.; Zhang, C. A mesoporous conjugated polymer based on a high free radical density polytriphenylamine derivative: Its preparation and electrochemical performance as a cathode material for Li-ion batteries. $J$. Mater. Chem. A 2017, 5, 2701-2709. [CrossRef]

38. Xiong, J.; Wei, Z.; Xu, T.; Zhang, Y.; Xiong, C.; Dong, L. Polytriphenylamine derivative with enhanced electrochemical performance as the organic cathode material for rechargeable batteries. Polymer 2017, 130, 135-142. [CrossRef]

39. Su, C.; Zhu, X.; Xu, L.; Zhou, N.; He, H.; Zhang, C. Organic polytriphenylamine derivative-based cathode with tailored potential and its electrochemical performances. Electrochim. Acta 2016, 196, 440-449. [CrossRef]

40. Zhu, L.; Cao, X. p-Dopable Poly(4-nitro)triphenylamine as Cathode Material with High Discharge Voltage for Lithium Ion Batteries. Int. J. Electrochem. Sci. 2015, 10, 4359-4365.

41. Zhu, L.; Cao, X. p-Dopable poly(4-cyano)triphenylamine: A high voltage organic cathode for lithium ion batteries. Mater. Lett. 2015, 150, 16-19. [CrossRef]

42. Xiang, J.; Sato, K.; Tokue, H.; Oyaizu, K.; Ho, C.-L.; Nishide, H.; Wong, W.-Y.; Wei, M. Synthesis and Charge-Discharge Properties of Organometallic Co-polymers of Ferrocene and Triphen-ylamine as Cathode Active Materials for Organic-Battery Applications. Eur. J. Inorg. Chem. 2016, 2016, 1030-1035. [CrossRef]

43. Su, C.; Yang, F.; Xu, L.; Zhu, X.; He, H.; Zhang, C. Radical Polymer Containing a Polytriphenylamine Backbone: Its Synthesis and Electrochemical Performance as the Cathode of Lithium-Ion Batteries. Chempluschem 2015, 80, 606-611. [CrossRef]

44. Gao, C.; Yan, D. Hyperbranched polymers: From synthesis to applications. Prog. Polym. Sci. 2004, 29, 183-275. [CrossRef]

45. Wei, Y.; Li, X.; Xu, Z.; Sun, H.; Zheng, Y.; Peng, L.; Liu, Z.; Gao, C.; Gao, M. Solution processible hyperbranched inverse-vulcanized polymers as new cathode materials in Li-S batteries. Polym. Chem. 2015, 6, 973-982. [CrossRef]

46. Zeigler, D.F.; Candelaria, S.L.; Mazzio, K.A.; Martin, T.R.; Uchaker, E.; Suraru, S.-L.; Kang, L.J.; Cao, G.; Luscombe, C.K. NType Hyperbranched Polymers for Supercapacitor Cathodes with Variable Porosity and Excellent Electrochemical Stability. Macromolecules 2015, 48, 5196-5203. [CrossRef]

47. Bhat, S.I.; Ahmadi, Y.; Ahmad, S. Recent Advances in Structural Modifications of Hyperbranched Polymers and Their Applications. Ind. Eng. Chem. Res. 2018, 57, 10754-10785. [CrossRef]

48. Cotter, R.J. Engineering Plastics: A Handbook of Polyarylethers; Gordon and Breach Publisher: Amsterdam, The Netherlands, 1995; ISBN 2884491120.

49. Lee, M.S.; Kim, S.Y. Synthesis of Poly(arylene ether)s Containing Triphenylamine Units via Nitro Displacement Reaction. Macromolecules 2005, 38, 5844-5845. [CrossRef]

50. Lee, J.; Heo, J.; Park, C.; Kim, B.-K.; Kwak, J.; Seo, M.; Kim, S.Y. Synthesis of triarylamine-containing poly(arylene ether)s by nucleophilic aromatic substitution reaction. J. Polym. Sci. Part A Polym. Chem. 2014, 52, 2692-2702. [CrossRef]

51. Carter, K.R. Aryl fluoride monomers in nucleophilic aromatic substitution polymerization: Evaluation of monomer reactivity by 19F NMR spectroscopy. Macromolecules 1995, 28, 6462-6470. [CrossRef]

52. Matsumoto, K.; Komuro, H.; Kai, T.; Jikei, M. Synthesis of poly(ether sulfone)s by self-polycondensation of AB-type monomers. Polym. J. 2013, 45, 909-914. [CrossRef]

53. Williams, F.J.; Donahue, P.E. Reactions of phenoxides with nitro- and halo-substituted phthalimides. J. Org. Chem. 1977, 42, 3414-3419. [CrossRef]

54. Markezich, R.L.; Zamek, O.S. Reactions of fluoride and nitrite ions with 4-nitrophthalimides. J. Org. Chem. 1977, 42, 3431-3434. [CrossRef]

55. White, D.M.; Takekoshi, T.; Williams, F.J.; Relles, H.M.; Donahue, P.E.; Klopfer, H.J.; Loucks, G.R.; Manello, J.S.; Matthews, R.O.; Schluenz, R.W. Polyetherimides via nitro-displacement polymerization: Monomer synthesis and 13C-NMR analysis of monomers and polymers. J. Polym. Sci. Polym. Chem. Ed. 1981, 19, 1635-1658. [CrossRef]

56. Takekoshi, T. Synthesis of High Performance Aromatic Polymers via Nucleophilic Nitro Displacement Reaction. Polym. J. 1987, 19, 191-202. [CrossRef]

57. Lee, H.S.; Kim, J.H. Measurement of Physical Properties of Conducting Polymers. Polym. Sci. Technol. 2007, 18, 488-495.

58. Peng, Z.; Yi, X.; Liu, Z.; Shang, J.; Wang, D. Triphenylamine-Based Metal-Organic Frameworks as Cathode Materials in LithiumIon Batteries with Coexistence of Redox Active Sites, High Working Voltage, and High Rate Stability. ACS Appl. Mater. Interfaces 2016, 8, 14578-14585. [CrossRef] 